\title{
Medicinal Plants Preferences for the Treatment of COVID-19 Symptoms in Central and Eastern Anatolia
}

\author{
Sefa AKBULUT*'] \\ Karadeniz Teknik University, Faculty of Forestry, Trabzon, TURKEY \\ *Corresponding Author: sakbulut@ktu.edu.tr
}

Received Date: 19.03.2021

Accepted Date: 04.05.2021

\begin{abstract}
Aim of study: This study aimed to determine the medicinal plant use preferences of herbalists' customers against the COVID-19 symptoms during pandemic period.

Area of study: The study was carried out in nine provinces located in the Central and Eastern Anatolia Region of Turkey and the herbalists selling medicinal plants.

Material and methods: Data on 35 plants from 373 customers and 49 herbalists were collected between April 2020 and December 2020. Relative Frequency of Citation (RFC) and Fidelity Level (FL) quantitative indices were used to measure the use, cultural significance, and specificity of plants.

Main results: The highest RFC was found for Thymus spp. (0.59). It was followed by Ceratonia siliqua L. (0.56), Zingiber officinale Roscoe (0.56), and Mentha pulegium L. (0.50), respectively. The plants in the study area with a high FL were Zingiber officinale $(84.83 \%)$ for cough, Thymus spp. (80.95\%) for fever, Mentha pulegium (76.47\%) for nausea-vomiting. Sambucus nigra L., Echinacea angustifolia DC., and Thymus spp. were the plants whose sales/demand increased the most during the pandemic period.

Highlights: It was understood that there was a significant increase in the sales of species such as Sambucus nigra, Echinacea angustifolia, and Thymus spp., during the pandemic period. This situation showed that there was a consensus among the public that these plants were effective against COVID-19 symptoms.
\end{abstract}

Keywords: Medicinal Plants, Herbalist, Customers, COVID-19, Symptoms, Turkey

Orta ve Doğu Anadolu'da COVID-19 Semptomlarının Tedavisi için Şifalı Bitkiler Tercihleri

Öz

Çalışmanın amacı: $\mathrm{Bu}$ çalışma, pandemi/COVID-19 döneminde aktar müşterilerinin hastalık belirtilerine karşı tıbbi bitki kullanım tercihlerini belirlemeyi amaçlamaktadır.

Çalışma alanı: Çalışma, Türkiye'nin İç ve Doğu Anadolu Bölgesi'nde yer alan dokuz ilde ve tıbbiaromatik bitki satan aktarlarda gerçekleștirilmiştir.

Materyal ve Yöntem: Nisan-Aralık 2020 döneminde toplam 373 müşteri ve 49 aktar ile yüz yüze anket uygulaması yapılmış ve 35 bitki hakkında veriler toplanmıştır. Kullanılan bitkilerin önemini, kullanım sıklığını ölçmek için Göreceli Atıf Sıklığı (RFC) ve Aslına Uygunluk Düzeyi (FL) gibi kantitatif indisler kullanılmıştır.

Temel Sonuçlar: En yüksek RFC, Thymus spp. için bulunmuştur (0.59). Bunu sırasılyla Ceratonia siliqua L. (0.56), Zingiber officinale Roscoe (0.56) ve Mentha pulegium L. (0.50) izlemiştir. Çalı̧şma alanındaki yüksek FL'ye sahip bitkiler öksürük için Zingiber officinale (84.83\%), ateş için Thymus spp. (80.95\%), bulant1-kusma için Mentha pulegium (76.47\%)'dur. Sambucus nigra L., Echinacea angustifolia DC. ve Thymus spp. pandemi döneminde satışları/talebi en çok artan bitkiler olarak belirlenmiştir.

Araştırma Vurguları: Pandemi döneminde Sambucus nigra, Echinacea angustifolia ve Thymus spp. gibi türlerin satışlarında önemli bir artış olduğu anlaşılmıştır. Bu durum, bitkilerin COVID-19 semptomlarına karşı etkili olduğu konusunda halk arasında bir fikir birliği olduğunu göstermektedir.

Anahtar Kelimeler: Şifalı Bitkiler, Aktar, Müşteri, COVID-19, Semptom, Türkiye 


\section{Introduction}

Medicinal plants are a significant part of public health despite the development of the health system. Traditional treatment in rural areas maintains its importance as the primary method in the usual seasonal diseases such as colds and flu. Treatment with medicinal plants has a special place in developed countries. The most important reason for medicinal plant treatment is the belief that it will encourage to healthier. Herbal remedies are a more moderate treatment method. Being as home remedies and over-thecounter medicines also increases the demand (Ekor, 2014). In recent years, there has been a significant increase in the general consumption of some plants such as mint, lemon, rosehip, ginger, and cinnamon. People think that these plants increase body resistance and protect the immune system against viruses (Toksoy et al., 2010).

Due to the COVID-19 virus that emerged at the end of 2019 and affected the world, interest in antiviral effects of plants has increased. Failure to find a $100 \%$ effective vaccine against the virus led to increased interest in the herbalists during the pandemic period.

COVID-19, the deadliest pandemic after the 1918 influenza pandemic, emerged in December 2019. The severe acute respiratory syndrome has caused by a virus called coronavirus 2 (SARS-CoV-2) by the World Health Organization (WHO) (Khan et al., 2021). COVID-19, a respiratory disease, has been recorded as the deadliest of all coronaviruses (Anonymous, 2021a). COVID-19 is infected by the contact of virus-carrying droplets that are suspended in the air to the nose, mouth, and eye areas of people (Guan et al., 2020). In various studies, it is stated that the most common symptoms caused by the virus are fever, cough, sore throat, shortness of breath, headache, weakness, anorexia, diarrhea, nauseavomiting, skin rash, and muscle-joint pain (Elshafeey et al., 2020; Guan et al., 2020; Huang et al., 2020; Wang et al., 2020; Zhou et al., 2020).

The active ingredients of many plants are effective against respiratory diseases and viruses. There are studies on the antiviral properties of medicinal plants and their efficient use. Sambucus nigra L., Allium sativum L., Allium cepa L., Citrus limon (L.) Osbeck, Melissa officinalis L., Morus spp., and Agave americana L. are examples of plants used for antiviral purposes (Ege and Elmastaş, 2020). 25\% of common medicinal compounds contain plant-based ingredients. (Khan et al., 2021).

The inadequacy of medicinal treatments has led people to use medicinal plants more effectively and widely (Öztürk et al., 2020). Many plants widely used for respiratory diseases in folk medicine (Satıl \& Selvi, 2020; Satıl \& Açar, 2020) and traditional therapy have been recorded from past to present (Cakilcioglu et al., 2011; Akbulut \& Bayramoglu, 2013; Gilling et al., 2014; Sargin, 2015; Li et al., 2017; Porter \& Bode, 2017; Hussein \& Dhabe, 2018; Akbulut et al., 2019; Ekşi et al., 2020; Erşen-Bak \& Çifci, 2020). About 13000 plant taxa are found within Turkey, and endemism rates reach 32\% (Özhatay et al., 2019; 2017; 2015; 2013). However, the rate of using plant species in Turkey for medicinal and aromatic purposes is approximately 3\% (TOŞ, 2019).

This study aimed to determine which medicinal plants sold in herbalists during the pandemic were the most preferred, which plants customers used for which symptoms, and the awareness of medicinal plants before and after the pandemic.

\section{Material and Methods \\ Study Area}

The study was carried out in nine provinces located in the Central and Eastern Anatolia Region of Turkey (Table 1, Figure 1). The Eastern Anatolia is the region of Turkey with the largest area and the lowest population density. The rural population is higher than the urban population (Anonymous, 2021b). The main livelihoods of the population are livestock and agriculture. The Central Anatolia is also the second-largest region of Turkey in terms of both area and population density. It is known as the granary of Turkey (Anonymous, 2021c). According to the Ministry of Health's COVID-19 Weekly Situation Report, these regions were the places where the number of cases increases the most (Sağlık Bakanlığ 2020). So, it has been chosen as a study area. 
The provinces were also selected subjectively.

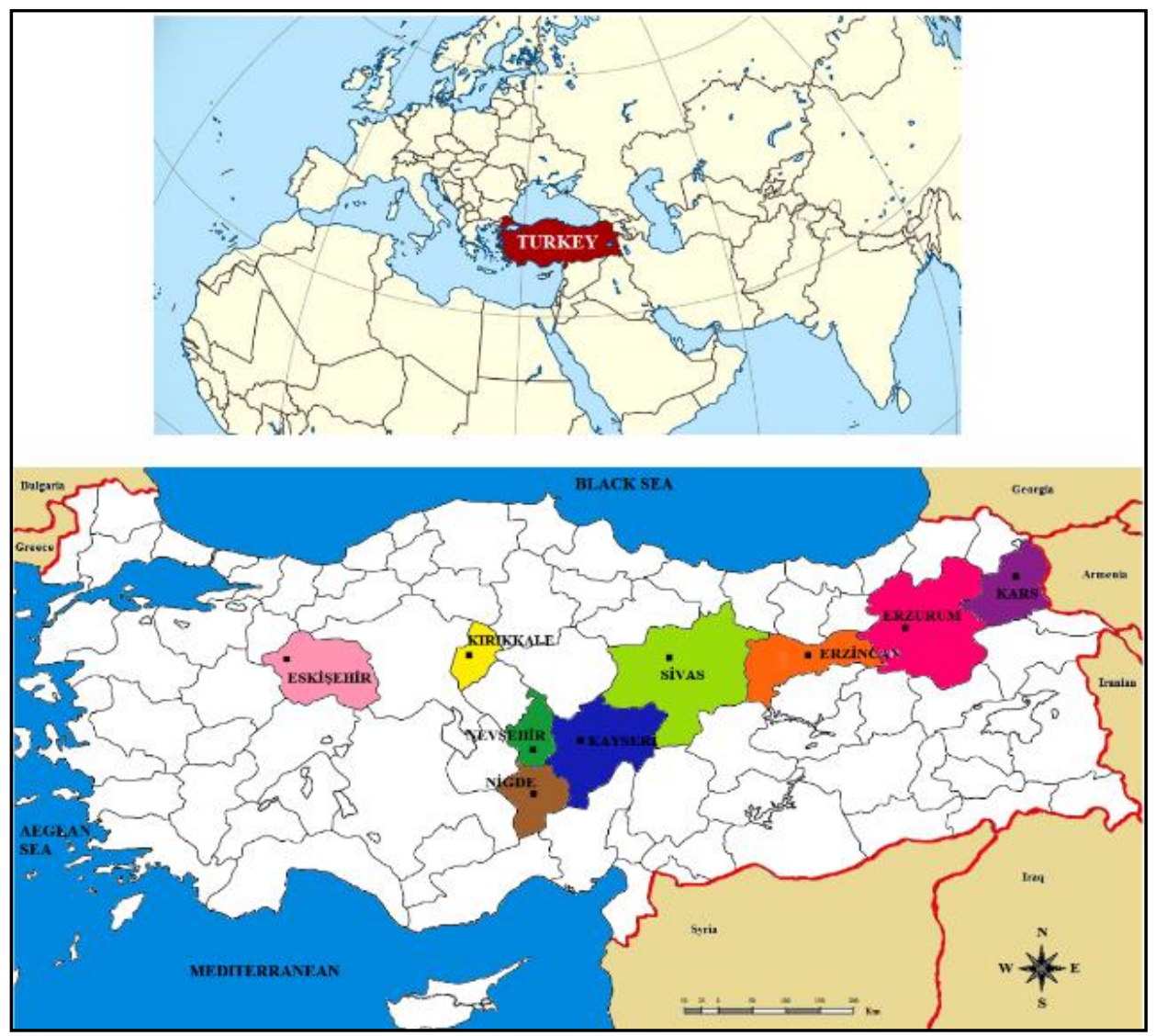

Figure 1. The geographical location of the study area

Table 1. Questionnaire totals and study locations

\begin{tabular}{llcc}
\hline Region & Province & $\begin{array}{c}\text { No. of } \\
\text { Herbalists }\end{array}$ & $\begin{array}{c}\text { No. of } \\
\text { Customers }\end{array}$ \\
\hline \multirow{4}{*}{$\begin{array}{l}\text { Central } \\
\text { Anatolia }\end{array}$} & Eskişehir & 10 & 59 \\
\cline { 2 - 4 } & Kayseri & 6 & 60 \\
\cline { 2 - 4 } & Kırıkkale & 3 & 25 \\
\cline { 2 - 4 } & Nevşehir & 3 & 26 \\
\cline { 2 - 4 } & Niğde & 5 & 38 \\
\cline { 2 - 4 } & Sivas & 9 & 49 \\
\hline \multirow{2}{*}{ Eastern } & Erzincan & 5 & 40 \\
\cline { 2 - 4 } Anatolia & Erzurum & 5 & 36 \\
\cline { 2 - 4 } & Kars & 3 & 40 \\
\hline Total & & 49 & 373 \\
\hline
\end{tabular}

\section{Data Collection}

The study included forty-nine herbalists and three hundred and seventy-three customers in Central and Eastern Anatolia of Turkey. Data were collected from April 2020 to December 2020. In the study, a face-toface questionnaire consisting of two parts was applied to both groups. In the first part of the questionnaires, questions were asked to determine the demographic characteristics of the participants. In the second part, the most preferred plant species during the COVID-19 pandemic period, the disease symptom of which they were preferred, and the way of use were tried to be determined (Appendix). Medicinal plants were named according to The Plant List (The Plant List, 2020) and the Flora of Turkey (Davis, 19651985; Davis et al., 1988; Güner et al., 2000; Güner et al., 2012).

\section{Data Analysis}

Data analyses were performed based on medicinal plant uses information provided by the herbalist's customers and using various statistical methods. Relative Frequency of Citation (RFC) and Fidelity Level (FL) of plants in the study area were calculated. 
The Relative Frequency of Citation (RFC) was calculated to assess the consensus among informants on reported plants for the treatment of COVID-19 disease (Vitalini et al., 2013; Yaseen et al., 2015). In calculating the RFC, the formula;

$$
\mathrm{RFC}=\mathrm{FC} / \mathrm{N}(0<\mathrm{RFC}<1)
$$

FC is the number of informants who mentioned the use of the species and $\mathrm{N}$ is the total number of informants. (Tardío \& Pardode-Santayana, 2008).

FL refers to the specificity of the plant species of choice for the diseases most frequently reported by informants. In calculating the FL, the formula;

$$
\mathrm{FL}(\%)=(\mathrm{Ip} / \mathrm{Iu}) * 100
$$

Ip is the number of informants that suggested the use of a plant for a specific ailment and $\mathrm{Iu}$ is the total number of informants who mentioned that a species is used to treat any ailment (Friedman et al., 1986).

\section{Results and Discussion}

The surveys were conducted with 373 customers and 49 herbalists. The results regarding the demographic characteristics of customers and herbalists were given in Table 2 . The ages of customers ranged from 21 to 78 years, with an average age of 45 years, and an average length of education of 12.5 years. The ages of herbalists ranged from 29 to 64 years, with an average age of 45 years, and an average length of education of 12.6 years. 201 customers were women (53.89\%) and 172 customers were men (46.11\%). All herbalists were male.

Data on the medicinal use of 35 plants belonging to 14 families were given in Table 3. Taxonomic order was done alphabetically according to first by family and then by scientific names. The most preferred families for use in the treatment of COVID-19 symptoms were Lamiaceae (6 taxa) and Asteraceae (5 taxa).

\begin{tabular}{|c|c|c|c|c|}
\hline Features & $\begin{array}{l}\text { Number of } \\
\text { Customers }\end{array}$ & Percentage $(\%)$ & $\begin{array}{l}\text { Number of } \\
\text { Herbalists }\end{array}$ & Percentage (\%) \\
\hline \multicolumn{5}{|l|}{ Age groups } \\
\hline $21-40$ & 150 & 40.21 & 20 & 40.82 \\
\hline $41-60$ & 164 & 43.97 & 22 & 44.90 \\
\hline$>60$ & 59 & 15.82 & 7 & 14.29 \\
\hline \multicolumn{5}{|l|}{ Gender } \\
\hline Male & 172 & 46.11 & 47 & 95.92 \\
\hline Female & 201 & 53.89 & 2 & 4.08 \\
\hline \multicolumn{5}{|l|}{ Education } \\
\hline Elementary school & 27 & 7.24 & 2 & 4.08 \\
\hline Secondary school & 50 & 13.40 & 8 & 16.33 \\
\hline High school & 155 & 41.56 & 20 & 40.82 \\
\hline University & 141 & 37.80 & 19 & 38.77 \\
\hline
\end{tabular}

Table 2. Demographic characteristics of customers and herbalists

Artemisia dracunculus L., Echinacea angustifolia DC., Cassia fistula L., Salvia officinalis L., Cinnamomum verum J.Presl, Cinnamomum camphora (L.) J.Presl, Hibiscus syriacus L., Curcuma longa L., and Zingiber officinale Roscoe are exotic plants for Turkey and sold as packaged products under various brands in medicinal plants. However, due to the increasing demand in recent years, production gardens have been established for Salvia officinalis (Tuğlu \& Baydar, 2019) and Artemisia dracunculus (Kan et al., 2020).

The most used parts of the plants sold were leaves (11 taxa). Flowers came second (7 taxa) and fruits came third (4 taxa). Other plant parts used were aerial parts, barks, cones, fruits, rhizomes, roots, seeds, and 
stems. The most preferred using method was determined as an infusion (22 taxa). Powder took second place (9 taxa), followed by decoction, essential oil, boiled, molasse, tablet, crushed, fresh, and gargle, respectively.

Herbalists and customers stated that these plants were mostly preferred for the treatment of anorexia, cough, diarrhea, fever, headache, muscle-joint pain, nauseavomiting, sore throat, shortness of breath, skin rash, and weakness symptoms. Both herbalists and customers had preferred to use these plants in cases where similar symptoms were seen even if COVID-19 had not been diagnosed.

The Relative Frequency of Citation (RFC) of plants depends on the number of informants providing information about the plant uses. In the study, RFC values ranged from 0.02 to 0.95 . The highest RFC was found for Thymus spp. Other taxa with high RFC values included Ceratonia siliqua (0.56), Zingiber officinale (0.56), and Mentha pulegium (0.50). Thymus genus is widely used all over the world for different purposes such as medicinal, food, and spice (Leal et al., 2017). The plant is used in traditional treatment in the old world due to its antiviral, antioxidant, and antiseptic properties (Stahl-Biskup, 2002). Properties of thyme have also been proven medically (Huang et al., 1994; Liu, 1995; Liu, 2005; Behrava et al., 2011). During the pandemic period, the emergence of anti-virus plants has increased the interest in thyme in Turkey and the research area. Zingiber officinale is one of the herbs that can be used as food, spice, and medicine all over the world (Badreldin et al., 2008; Osmanlığlu-Dağ \& Kuruüzüm$\mathrm{Uz}, 2018$ ).

Especially in traditional medicine in India, China and Tibet, it has been used in the treatment of many diseases such as cold, rheumatism, nerve diseases, gingivitis, toothache, asthma, paralysis, constipation, diabetes, cough, menstrual cramps, cancer, and colds (Shukla \& Singh, 2007). Ceratonia siliqua and Mentha pulegium are similarly widely used plants in Turkey, both for food and for their different healing properties (Ertuğ, 2004; Ugulu et al., 2009; Gürdal \&
Kültür, 2013). Mentha spp., Ceratonia siliqua, and Thymus spp. were among the best-selling herbs with high RFC values in a study conducted with herbalists in Kahramanmaraş (southeast Turkey) (Uzun \& Koca, 2020).

The fidelity level (FL) of the most important plant taxa ranged from $52.04 \%$ to $84.83 \%$ (Table 4). The high FL of a plant indicates the prevalence of a specific disease in a country and the utilization of plants by the local people to treat it (Srithi et al., 2009; Bibi et al., 2014; Umair et al., 2017). In this study, the FL value was calculated by considering only the symptoms of COVID19 disease instead of the disease groups.

The plants in the study area with a high FL were Zingiber officinale (84.83\%) for cough, Thymus spp. (80.95\%) for fever, Mentha pulegium (76.47\%) for nauseavomiting, Salvia absconditiflora and Salvia officinalis $(72.09 \%)$ for sore throat, Ceratonia siliqua (70\%) for weakness, Curcuma longa $(68.75 \%)$ for muscle-joint pain, Salvia absconditiflora and Salvia officinalis $(68.33 \%)$ for shortness of breath, Cinnamomum camphora (65.52\%) for skin rash, Ceratonia siliqua $(60.87 \%)$ for diarrhea, Cinnamomum verum $(60.56 \%)$ for anorexia, and Mentha pulegium (52.04\%) for headache. According to a study conducted in Turkey among the reasons people purchase medicinal plants were located in the first place the digestive system disorders. Respiratory disorders came also second. The most preferred plants were Mentha pulegium and Zingiber officinale for food-spice, Foeniculum vulgare, Mentha pulegium, and Nigella sativa for digestive system disorders, Tilia tomentosa, Zingiber officinale, and Rosa canina for respiratory system disorders (Akbulut \& Bayramoglu, 2013). 
Table 3. Plants most preferred by customers against COVID-19 in Central and Eastern Anatolia of Turkey

\begin{tabular}{|c|c|c|c|c|c|c|c|c|}
\hline Family & Botanical name & Common name & Vernacular name & Part used & Preparations & Used symptom & FC & RFC \\
\hline Apiaceae & Anethum graveolens $\mathrm{L}$. & Dill & Dereotu & $\mathrm{L}, \mathrm{S}$ & infusion, fresh & anorexia & 10 & 0.03 \\
\hline Apiaceae & Foeniculum vulgare Mill. & Sweet fennel & Rezene & $\mathrm{S}$ & infusion & shortness of breath & 20 & 0.05 \\
\hline Asteraceae & Achillea millefolium $\mathrm{L}$. & Common yarrow & Civanperçemi & $\mathrm{Fl}$ & $\begin{array}{l}\text { infusion, } \\
\text { crushed }\end{array}$ & $\begin{array}{c}\text { weakness, cough, sore throat, nausea- } \\
\text { vomiting }\end{array}$ & 52 & 0.14 \\
\hline Asteraceae & Anthemis spp. & Dog-fennel & Papatya & $\mathrm{Fl}$ & infusion & sore throat, anorexia, fever & 28 & 0.08 \\
\hline Asteraceae & Artemisia dracunculus L.* & Tarragon & Darhun & $\mathrm{L}$ & powder & fever, muscle-joint pain, anorexia & 25 & 0.07 \\
\hline Asteraceae & Echinacea angustifolia DC.* & $\begin{array}{l}\text { Narrow-leaved purple } \\
\text { coneflower }\end{array}$ & Ekinezya & Rt & powder & $\begin{array}{l}\text { fever, cough, shortness of breath, muscle- } \\
\text { joint pain }\end{array}$ & 89 & 0.24 \\
\hline Asteraceae & Matricaria chamomilla $\mathrm{L}$. & German chamomile & Alman papatyası & $\mathrm{Fl}$ & infusion & sore throat, anorexia, fever & 74 & 0.20 \\
\hline Boraginaceae & Alkanna orientalis (L.) Boiss. & Alkanet & Havaciva & Rt & decoction & skin rash, diarrhea & 12 & 0.03 \\
\hline Caprifoliaceae & Sambucus nigra L. & European elder & Kara mürver & $\mathrm{Fl}, \mathrm{Fr}$ & $\begin{array}{l}\text { powder } \\
\text { tablet }\end{array}$ & $\begin{array}{l}\text { fever, cough, shortness of breath, } \\
\text { weakness, muscle-joint pain }\end{array}$ & 126 & 0.34 \\
\hline Cupressaceae & Juniperus drupacea Labill. & Syrian juniper & Andiz & $\mathrm{C}$ & molasse & cough, nausea-vomiting, anorexia & 39 & 0.10 \\
\hline Fabaceae & Cassia fistula L.* & Golden shower tree & Sinameki & $\mathrm{S}, \mathrm{L}$ & infusion & skin rash, fever, sore throat, cough & 84 & 0.23 \\
\hline Fabaceae & Ceratonia siliqua $\mathrm{L}$. & Carob & Harnup & Fr & $\begin{array}{l}\text { decoction, } \\
\text { molases }\end{array}$ & cough, diarrhea, weakness, anorexia & 208 & 0.56 \\
\hline Fabaceae & Glycyrrhiza glabra L. & Licorice & Meyan kökü & Rt & $\begin{array}{l}\text { powder } \\
\text { infusion }\end{array}$ & $\begin{array}{l}\text { cough, shortness of breath, skin rash, } \\
\text { weakness, muscle-joint pain }\end{array}$ & 100 & 0.27 \\
\hline Lamiaceae & Melissa officinalis $\mathrm{L}$. & Common balm & Oğulotu & $\mathrm{L}$ & infusion & weakness, sore throat, cough, headache & 83 & 0.22 \\
\hline Lamiaceae & Mentha pulegium $\mathrm{L}$. & Pennyroyal & Yarpuz & $\mathrm{L}$ & infusion & $\begin{array}{c}\text { headache, sore throat, nausea-vomiting, } \\
\text { fever }\end{array}$ & 200 & 0.54 \\
\hline Lamiaceae & $\begin{array}{l}\text { Salvia absconditiflora } \text { Greuter \& } \\
\text { Burdet }\end{array}$ & Sage & Adaçayı & $\mathrm{L}$ & infusion & sore throat, shortness of breath & 56 & 0.15 \\
\hline Lamiaceae & Salvia officinalis $\mathrm{L} . *$ & Common sage & Adaçayı & $\mathrm{L}$ & infusion, gargle & sore throat, shortness of breath & 79 & 0.21 \\
\hline
\end{tabular}


Table 3. (Continued)

\begin{tabular}{|c|c|c|c|c|c|c|c|c|}
\hline Family & Botanical name & Common name & Vernacular name & Part used & Preparations & Used symptom & FC & $\mathrm{RFC}$ \\
\hline Lamiaceae & Sideritis spp. & Mountain tea & Dağçayı & $\mathrm{Fl}$ & infusion & fever, sore throat, cough & 115 & 0.31 \\
\hline Lamiaceae & Thymbra spicata $\mathrm{L}$. & Mediterranean thyme & Kekik & $\mathrm{L}$ & $\begin{array}{l}\text { infusion } \\
\text { essential oil }\end{array}$ & $\begin{array}{l}\text { anorexia, weakness, cough, skin } \\
\text { rash }\end{array}$ & 168 & 0.45 \\
\hline Lamiaceae & Thymus spp. & Thyme & Dağ kekiği & Ap & $\begin{array}{l}\text { infusion } \\
\text { essential oil }\end{array}$ & $\begin{array}{l}\text { cough, fever, sore throat, shortness } \\
\text { of breath }\end{array}$ & 221 & 0.59 \\
\hline Lauraceae & Cinnamoтит verum J.Pres1* & True cinnamon tree & Tarçın & B & $\begin{array}{l}\text { powder } \\
\text { infusion }\end{array}$ & $\begin{array}{c}\text { diarrhea, anorexia, cough, fever, } \\
\text { weakness }\end{array}$ & 100 & 0.27 \\
\hline Lauraceae & $\begin{array}{l}\text { Cinnamomum camphora (L.) } \\
\text { J.Presl* }\end{array}$ & Camphor tree & Kafur & St & essential oil & muscle-joint pain, skin rash & 11 & 0.03 \\
\hline Lauraceae & Laurus nobilis $\mathrm{L}$. & Bay laurel & Defne & $\mathrm{L}$ & infusion & $\begin{array}{l}\text { muscle-joint pain, weakness, skin } \\
\text { rash }\end{array}$ & 35 & 0.09 \\
\hline Malvaceae & Hibiscus syriacus L.* & Korean rose & Ağaç hatmi & $\mathrm{Fl}$ & infusion & $\begin{array}{l}\text { skin rash, diarrhea, cough, muscle- } \\
\text { joint pain }\end{array}$ & 65 & 0.17 \\
\hline Malvaceae & Malva neglecta Wallr. & Mallow & Ebegümeci & Ap & boiled & cough, weakness, fever & 20 & 0.05 \\
\hline Malvaceae & Malva sylvestris $\mathrm{L}$. & Common mallow & Ebegümeci & Ap & boiled & cough, weakness, fever & 15 & 0.04 \\
\hline Malvaceae & Tilia tomentosa Moench & Silver linden & Ihlamur & $\mathrm{Fl}$ & infusion & sore throat, cough, headache & 166 & 0.45 \\
\hline Moraceae & Morus alba $\mathrm{L}$. & Mulberry & Akdut & Fr & decoction & skin rash, weakness, cough & 100 & 0.27 \\
\hline Polygonaceae & Rumex patientia $\mathrm{L}$. & Patience dock & Evelik & $\mathrm{Rt}$ & decoction & skin rash, sore throat, fever & 14 & 0.04 \\
\hline Ranunculaceae & Nigella sativa $\mathrm{L}$. & Black cumin & Çörekotu & $\mathrm{S}$ & infusion & $\begin{array}{l}\text { skin rash, weakness, headache, } \\
\text { cough }\end{array}$ & 88 & 0.24 \\
\hline Rosaceae & Cerasus mahaleb (L.) Mill. & Mahaleb cherry & Mahleb & $\mathrm{S}$ & powder & anorexia, shortness of breath & 35 & 0.09 \\
\hline Rosaceae & Rosa canina $\mathrm{L}$. & Dog rose & Kuşburnu & Fr, L & $\begin{array}{l}\text { infusion } \\
\text { powder }\end{array}$ & $\begin{array}{l}\text { weakness, fever, cough, diarrhea, } \\
\text { sore throat }\end{array}$ & 188 & 0.50 \\
\hline Rosaceae & Rubus caesius $\mathrm{L}$. & Dewberry & Büküzümü & $\mathrm{L}$ & infusion & diarrhea, weakness, skin rash & 9 & 0.02 \\
\hline Zingiberaceae & Curcuma longa $\mathrm{L} . *$ & Turmeric & Zerdeçal & $\mathrm{Rh}$ & $\begin{array}{l}\text { powder } \\
\text { decoction }\end{array}$ & $\begin{array}{l}\text { fever, cough, sore throat, muscle- } \\
\text { joint pain }\end{array}$ & 147 & 0.39 \\
\hline Zingiberaceae & Zingiber officinale Roscoe* & Ginger & Zencefil & $\mathrm{Rh}$ & $\begin{array}{l}\text { infusion } \\
\text { powder }\end{array}$ & $\begin{array}{l}\text { nausea-vomiting, fever, cough, } \\
\text { shortness of breath, sore throat }\end{array}$ & 209 & 0.56 \\
\hline
\end{tabular}

*Exotic species in Turkey, Ap: Aerial parts, B: Bark, C: Cone, Fl: Flower, Fr: Fruit, L: Leaf, Rh: Rhizome, Rt: Root, S: Seed, St: Stem. 
Table 4. Medicinal species for the most frequently reported symptoms of COVID-19 disease based on the fidelity level index

\begin{tabular}{llc}
\hline Taxa & Uses & Fidelity level (FL - \%) \\
\hline Thymus spp. & Fever & 80.95 \\
\hline Zingiber officinale & Cough & 84.83 \\
\hline $\begin{array}{l}\text { Salvia absconditiflora } \\
\text { Salvia officinalis }\end{array}$ & Sore throat & 72.09 \\
\hline Salvia absconditiflora Salvia officinalis & Shortness of breath & 68.33 \\
\hline Mentha pulegium & Headache & 52.04 \\
\hline Ceratonia siliqua & Weakness & 70.00 \\
\hline Cinnamomum verum & Anorexia & 60.56 \\
\hline Ceratonia siliqua & Diarrhea & 60.87 \\
\hline Mentha pulegium & Nausea-vomiting & 76.47 \\
\hline Cinnamomum camphora & Skin rash & 65.52 \\
\hline Curcuma longa & Muscle-joint pain & 68.75 \\
\hline
\end{tabular}

Customers preferred to use powdered plants as a mixture. While they mix Cinnamomum verum and Zingiber officinale powder with honey, coffee, or salep, they mostly mix Thymus spp. with olive oil. They preferred to sweeten Melissa officinalis and Mentha pulegium with lemon.

Herbalists stated that species such as Tilia tomentosa, Zingiber officinale, Rosa canina, and Mentha pulegium, which were mostly sold in the autumn-winter period before the pandemic, reached high sales rates in the summer months.

Herbalists stated that before the pandemic, customers received advice while purchasing medicinal plants and made their choices accordingly. Besides, they said that during the pandemic period, customers preferred specific plants for specific symptoms. Customers declared that they behaved according to the information they obtained from communication and social media channels when purchasing medicinal plants during this period.

None of the customers was diagnosed with COVID-19. They reported that they took and used medicinal plants for caution. That showed the public was adequately informed about the pandemic and the pandemic was taken seriously.

Herbalists reported that interest in plants such as Sambucus nigra and Echinacea angustifolia increased considerably during the pandemic period. They stated that the demand for these plants, which were not listed at the top of the sales lists before, could not be met during the pandemic period. Also, they stated that the demand for Thymus species increased considerably during the pandemic period. It has been reported that thyme was mostly used as a spice before but was also requested for healing purposes during the pandemic period. In Turkey, Origanum, Thymbra, Satureja genus are sold under the name thyme. However, it has been declared that during the pandemic period, customers especially wanted the Thymus genus. The situation before and after the pandemic can be noticed in studies on medicinal-aromatic plant sales and plant species sold (Toksoy et al., 2010; Akbulut and Bayramoglu, 2013; Akbulut and Özkan, 2016).

\section{Conclusion}

In this study, carried out in the Central and Eastern Anatolia Regions of Turkey, 35 plant taxa that were sold/requested the most during the COVID-19 period were determined. These plants are generally at the top of herbal sales lists. However, it was understood that there was a significant increase in the sales of species such as Sambucus nigra, Echinacea angustifolia, and Thymus spp., during the pandemic period. This situation shows that there is a consensus among the public that these plants are effective against COVID-19 symptoms. Especially, the increase in scientific studies 
on antiviral plants and their effects and the widespread sharing of these studies in the media were efficient for social awareness.

The pandemic has brought significant dynamism especially in the medicinal plant market and has had positive effects on the number of plant species that can be used and in product development. Due to the increasing interest in natural extracts, it has been observed that the sales of herbal drugs and product range have increased.

People who adopt traditional treatment methods have increased in search of new products, and it has been understood that they are particularly enthusiastic about what plants can be more effective against COVID19.

The fact that some of the most sold plants were exotic species in Turkey has shown that people are not limited to their regions in terms of health.

This study once again demonstrated the importance of medicinal plants for alternative treatment and public health during crisis periods such as pandemics.

\section{Acknowledgments}

The author sincerely thanks local expertwitnesses, who have assisted and guided the questionnaire studies, and the herbalists and the people who have participated in the study.

\section{Ethics Committee Approval}

Prior Informed Consent (PIC) was taken orally before starting each interview. Ethical guidelines followed the Code of Ethics of the International Society for Ethnobiology (http://ethnobiology.net/code-of-ethics/) (https://www.ethnobiology.net/wpcontent/uploads/ISECOE_Eng_rev_24Nov08.pdf)

\section{Peer-review}

Externally peer-reviewed.

\section{Author Contributions}

Conceptualization: S.A..; Investigation: S.A., S.A.; Material and Methodology: S.A.; Supervision: S.A.; Visualization: S.A.; Writing-Original Draft: S.A.; Writing-review \& Editing: S.A.; Other: Author has read and agreed to the published version of manuscript.

\section{Conflict of Interest}

The author has no conflicts of interest to declare.

\section{Funding}

The author declared that this study has received no financial support.

\section{References}

Akbulut, S. \& Bayramoglu, M. M. (2013). The trade and use of some medicinal and aromatic herbs in Turkey. Studies on Ethno-Medicine, 7, 67-77.

Akbulut, S. \& Özkan, Z. C. (2016). Herbalistcustomer profile in medicinal and aromatic herbs trade: a case study of Kahramanmaraş, Turkey. Kastamonu University Journal of Forestry Faculty, 16(1), 246-252.

Akbulut, S., Karaköse, M. \& Özkan, Z. C. (2019). Traditional uses of some wild plants in Kale and Acipayam provinces in Denizli. Kastamonu University Journal of Forestry Faculty, 19(1), 72-81. doi.org/ 10.17475/kastorman.543529.

Anonymous (2021a). Coronavirus. https://www.worldometers.info/coronavirus/ (Accessed 28.01.2021)

Anonymous (2021b). Doğu Anadolu Bölgesi. https://tr.wikipedia.org/wiki/Doğu_Anadolu Bölgesi\#Nüfus_ve_yerleşme (Accessed 30.04.2021).

Anonymous (2021c). İç Anadolu Bölgesi. https://tr.wikipedia.org/wiki/İç_Anadolu_Bölg esi (Accessed 30.04.2021).

Badreldin, H. A., Blunden, G., Tanira, M. O. \& Nemmar, A. (2008). Some phytochemical, pharmacological and toxicological properties of ginger (Zingiber officinale Roscoe): a review of recent research. Food and Chemical Toxicology, 46, 409-420.

Behrava. J., Ramexani, M., Nobandegan, E. F. \& Gharaee, M. E. (2011). Antiviral and antimicrobial activity of Thymus transcaspicus essential oil. Pharmacologyonline, 1, 1190-1199.

Bibi, T., Ahmad, M., Tareen, R. B., Tareen, N. M., Jabeen, R., Rehman, S., Sultana, S., Zafar, M. \& Yaseen, G. (2014). Ethnobotany of medicinal plants in district Mastung of Balochistan province-Pakistan. Journal of Ethnopharmacology, 157, 79-89. doi.org/10.1016/j.jep.2014.08.042.

Cakilcioglu, U., Khatun, S., Turkoglu, I. \& Hayta, S. (2011). Ethnopharmacological survey of 
medicinal plants in Maden (Elazig - Turkey). Journal of Ethnopharmacology, 137, 469-486. doi.org/10.1016/j.jep.2011.05.046.

Davis, P. H. (1965-1985). Flora of Turkey and the East Aegean Islands, 1-9. Edinburgh: Edinburgh University Press.

Davis, P. H., Mill, R. R. \& Tan, K. (1988). Flora of Turkey and the East Aegean Islands, 10. Edinburgh: Edinburgh University Press.

Ege, M. \& Elmastaş, M. (2020). Antiviral etkili fitoterapötikler: tıbbi bitkiler ve fitokimyasallar. Journal of Integrative and Anatolian Medicine, 1(2), 5-20.

Ekor, M. (2014). The growing use of herbal medicines: issues relating to adverse reactions and challenges in monitoring safety. Frontiers in Pharmacology, 4, 177. doi.org/10.3389/fphar.2013.00177.

Ekşi, G., Özkan, A. M. G. \& Koyuncu, M. (2020). Garlic and onions: an eastern tale. Journal of Ethnopharmacology, 253, 112675. doi.org/10.1016/j.jep.2020.112675.

Elshafeey, F., Magdi, R., Hindi, N., Elshebiny, M., Farrag, N. \& Nabhan, N. (2020). A systematic scoping review of COVID-19 during pregnancy and childbirth. International Journal of Gynecology \& Obstetrics, 150, 4752. doi.org/10.1002/ijgo.13182.

Erşen-Bak, F. \& Çifci, K. (2020). Traditional uses of some medicinal plants in the central villages of Artvin. Artvin Coruh University Journal of Forestry Faculty, 21(2), 318-329. doi.org/10.17474/artvinofd.782235.

Ertuğ, F. (2004). Wild edible plants of the Bodrum area (Muğla, Turkey). Turkish Journal of Botany, 28, 161-174.

Friedman, J., Yaniv, Z., Dafni, A. \& Palewitch, D. (1986). A preliminary classification of the healing potential of medicinal plants, based on a rational analysis of an ethnopharmacological field survey among Bedouins in the Negev Desert, Israel. Journal of Ethnopharmacology, 16(2-3), 275-287. doi.org/10.1016/03788741(86)90094-2.

Gilling, D. H., Kitajima, M., Torrey, J. \& Bright, K. R. (2014). Antiviral efficacy and mechanisms of action of oregano essential oil and its primary component carvacrol against murine norovirus. Journal of Applied Microbiology, 116(5), 1149-1163. doi.org/10.1111/jam.12453.

Guan, W., Ni, Z., Hu, Y., Liang, W., Ou, C. \& Zhong, N. (2020). Clinical characteristics of 2019 novel coronavirus infection in China. New England Journal of Medicine, 382, 17081720. doi.org/10.1056/NEJMoa2002032.

Güner, A., Özhatay, N., Ekim, T. \& Başer, K. H. C. (2000). Flora of Turkey and the East
Aegean Islands, 11. Edinburgh: Edinburgh University Press.

Güner, A., Aslan, S., Ekim, T., Vural, M. \& Babaç, M. T. (2012). Türkiye Bitkileri Listesi (Damarlı Bitkiler). İstanbul: Nezahat Gökyiğit Botanik Bahçesi ve Flora Araştırmaları Derneği Yayını.

Gürdal, B. \& Kültür, Ş. (2013). An ethnobotanical study of medicinal plants in Marmaris (Muğla, Turkey). Journal of Ethnopharmacology, 146, 113-126. doi:10.1016/j.jep.2012.12.012.

Huang, C., Wang, Y., Li, X., Ren, L., Zhao, J. \& Cao, B. (2020). Clinical features of patients infected with 2019 novel coronavirus in Wuhan, China. Lancet, 395, 497-506.

Huang, M. T., Ho, C. T., Wang, Z. Y., Ferraro, T., Lou, Y. R. \& Conney, A. H. (1994). Inhibition of skin tumorigenesis by rosemary and its constituents carnosol and ursolic acid. Cancer Research, 54(3), 701-708.

Hussein, S. \& Dhabe, A. (2018). Ethnobotanical study of folk medicinal plants used by villagers in Hajjah district - Republic of Yemen. Journal of Medicinal Plants Studies, 6(5), 24-30.

Kan, Y., Kevseroğlu, K., Çalışkan, Ö., Akbulut, S., Çelik, A. S. \& Ayran, İ. (2020). DOKAP bölgesinde tıbbi ve aromatik bitki yetiştiriciliğinin yaygınalşıtırlması projesi e ğitim kitabı. Konya: Sayram Yayınları.

Khan, T., Khan, M. A., Mashwani, Z. R., Ullah, N. \& Nadhman, A. (2021). Therapeutic potential of medicinal plants against COVID19: The role of antiviral medicinal metabolites. Biocatalysis and Agricultural Biotechnology, 31,101890. doi.org/10.1016/j.bcab.2020.101890.

Leal, F., Taghouti, M., Nunes, F., Silva, A., Coelho, A. C. \& Matos, M. (2017). Thymus Plants: A Review-Micropropagation, Molecular and Antifungal Activity. In: Active Ingredients from Aromatic and Medicinal Plants. Egypt: Cairo University.

Li, Y., Liu, Y., Ma, A., Bao, Y., Wang, M. \& Sun, Z. (2017). In vitro antiviral, antiinflammatory, and antioxidant activities of the ethanol extract of Mentha piperita L. Food Science and Biotechnology, 26(6), 1675-1683. doi.org/10.1007/s10068-017-0217-9.

Liu, J. (1995). Pharmacology of oleanolic acid and ursolic acid. Journal of Ethnopharmacology, 49, 57-68.

Liu, J. (2005). Oleanolic acid and ursolic acid: research perspectives. Journal of Ethnopharmacology, 100, 92-94.

Osmanlıoğlu-Dağ, Ş. R. \& Kuruüzüm-Uz, A. (2018). Ginger's place in pharmacy and 
antitumor effect. Hacettepe University Journal of the Faculty of Pharmacy, 38(2), 76-84.

Özhatay, N., Kültür, Ş. \& Gürdal, B. (2019). Check-list of additional taxa to the supplement flora of Turkey IX. Journal of the Faculty of Pharmacy of Istanbul University, 49(2), 105120. https://doi.org/http://dx.doi.org/10.26650 /IstanbulJPharm.2019.19037

Özhatay, N., Kültür, Ş. \& Gürdal, B. (2017). Check-list of additional taxa to the supplement flora of Turkey VIII. Journal of the Faculty of Pharmacy of Istanbul University, $\quad 47(1), \quad 31-47$. https://doi.org/http://dx.doi.org/10.5152/Istanb ulJPharm.2017.006

Özhatay, N., Kültür, Ş. \& Gürdal, B. (2015). Check-list of additional taxa to the Supplement Flora of Turkey VII. Journal of the Faculty of Pharmacy of Istanbul University, 45(1), 61-86.

Özhatay, N., Kültür, Ş. \& Gürdal, B. (2013). Check-list of additional taxa to the Supplement Flora of Turkey VI. Journal of the Faculty of Pharmacy of Istanbul University, 43(1), 33-83.

Öztürk, Y. E., Dömbekçi, H. A. \& Ünal, S. N. (2020). Geleneksel tamamlayıc1 ve alternatif tıp kullanımı. Jpurnal of Integrative and Anatolian Medicine, 1(3), 23-35.

Porter, R. S. \& Bode, R. F. (2017). A review of the antiviral properties of black elder (Sambucus nigra L.) products. Phytotherapy Research, 31(4), 533-554. doi.org/10.1002/ptr.5782.

Sağlık Bakanlığı (2020). COVID-19 haftalık durum raporu. https://covid19.saglik.gov.tr/TR-68443/covid19-durum-raporu.html (Accessed 30.11.2020).

Sargin, S. A. (2015). Ethnobotanical survey of medicinal plants in Bozyazı district of Mersin, Turkey. Journal of Ethnopharmacology, 173, 105-126. doi.org/10.1016/j. jep.2015.07.009.

Satıl, F. \& Açar, M. (2020). Ethnobotanical use of Stachys L. (Lamiaceae) taxa in Turkey, International Journal of Nature and Life Sciences, 4(2), 66-86.

Sat1l, F. \& Selvi, S. (2020). Ethnobotanical features of Ziziphora L. (Lamiaceae) taxa in Turkey. International Journal of Nature and Life Sciences, 4(1), 56-65.

Stahl-Biskup, E. (2002). Thyme as a herbal drug pharmacopoeias and other product characteristics. In: Thyme: The Genus Thymus. London: CRC Press Taylor \& Francis Group.

Shukla, Y. \& Singh, M. (2007). Cancer preventive properties of zinger: a brief review.
Food and Chemical Toxicology, 45(5), 683690. doi.org/10.1016/j.fct.2006.11.002.

Srithi, K., Balslev, H., Wangpakapattanawong, P., Srisanga, P. \& Trisonthi, C. (2009). Medicinal plant knowledge and its erosion among the Mien (Yao) in northern Thailand. Journal of Ethnopharmacology, 123(2), 335-342. doi.org/10.1016/j.jep.2009.02.035.

Tardío, J. \& Pardo-de-Santayana, M. (2008). Cultural importance indices: a comparative analysis based on the useful wild plants of Southern Cantabria (Northern Spain). Economic Botany, 62(1), 24-39.

The Plant List (2020). A working list of all plant species. http://www.theplantlist.org/ (Accessed 10.12.2020).

Toksoy, D., Bayramoğlu, M. M. \& Hacısalihoğlu, S. (2010). Usage and the economic potential of the medicinal plants in Eastern Black Sea Region of Turkey. Journal of Environmental Biology, 31, 623-628.

TOŞ (2019). Orman kaynaklarından faydalanma grubu çalışma belgesi. Tarım Orman Şurası, https://cdniys.tarimorman.gov.tr/api/File/GetG aleriFile/330/DosyaGaleri/956/21\%20Orman $\% 20$ Kaynaklar\%C4\%B1ndan\%20Faydalanma $\% 20 \mathrm{Grubu} \% 20 \% \mathrm{C} 3 \% 87 \mathrm{al} \% \mathrm{C} 4 \% \mathrm{~B} 1 \% \mathrm{C} 5 \% 9 \mathrm{~F}$ ma\%20Belgesi.pdf. (Accessed 10.03.2021).

Tuğlu, Ü. \& Baydar, H. (2019). Agronomic and technological properties of b-clones developed by clonal selection of common sage (Salvia officinalis L.). Süleyman Demirel University Journal of Natural and Applied Sciences, 23(2), 452-456. doi.org/10.19113/sdufenbed.514564.

Ugulu, I., Baslar, S., Yorek, N. \& Dogan, Y. (2009). The investigation and quantitative ethnobotanical evaluation of medicinal plants used around Izmir province, Turkey. Journal of Medicinal Plant Research, 3(5), 345-367.

Umair, M., Altaf, M. \& Abbasi, A. M. (2017). An ethnobotanical survey of indigenous medicinal plants in Hafizabad district, PunjabPakistan. Plos One, 12(6), e0177912. doi.org/10.1371/journal.pone.0177912.

Uzun, S. P. \& Koca, C. (2020). Ethnobotanical survey of medicinal plants traded in herbal markets of Kahramanmaraş. Plant Diversity, 42(2020), 443-454. doi.org/10.1016/j.pld.2020.12.003.

Vitalini, S., Iriti, M., Puricelli, C., Ciuchi, D., Segale, A. \& Fico, G. (2013). Traditional knowledge on medicinal and food plants used in Val San Giacomo (Sondrio, Italy)-an alpine ethnobotanical study. Journal of Ethnopharmacology, 145(2), 517-529.

Wang, D., Hu, B., Hu, C., Zhu, F., Liu, X. \& Peng, Z. (2020). Clinical characteristics of 
138 hospitalized patients with 2019 novel coronavirus-infected pneumonia in Wuhan, China. Jama, 323(11), 1061-1069. doi.org/10.1001/jama.2020.1585.

Yaseen, G., Ahmad, M., Sultana, S., Alharrasi, A. S., Hussain, J., Zafar, M. \& Ur-Rahman, S. (2015). Ethnobotany of medicinal plants in the Thar Desert (Sindh) of Pakistan. Journal of Ethnopharmacology, 163, 43-59.

Zhou, F., Ting, Y., Ronghui, D., Guohui, F., Ying, L. \& Cao, B. (2020). Clinical course and risk factors for mortality of adult inpatients with COVID-19 in Wuhan, China: a retrospective cohort study. Lancet, 395, 10541062. doi.org/10.1016/S0140-6736(20)305663.

\section{Appendix}

1. City: ......

2. Herbalist / Customer code:

3. Age, gender, educational level, permanent address.

4. What is the vernacular name of the plants?

5. Which parts of the plant do you use? (aerial parts, fruit, flower, leaf, root, etc.)

6. Which plants are recommended / claimed for COVID-19?

7. Which plants do you recommend / request for which symptoms?

8. Which parts of the plant do you use? (leaf, flower, fruit, aerial parts, bark, seed, etc.)

9. How do you prepare the plants? (infusion, decoction, essential oil, powder, etc.)

10. What are the recommended / requested herbal foods to increase body resistance in the treatment of COVID-19 disease?

11. Are plants in demand after or before COVID-19 disease?

12. Do you make a mixture for preventive or therapeutic purposes against COVID-19 disease?

13. Have you been diagnosed with COVID-19?

14. From whom / where do you learn plants effective against disease?

15. How did your plant sales list or sales amounts change during the pandemic period? 